\title{
Identification of a novel murine organic anion transporter like protein 1 (OATLP1) expressed in the kidney
}

\author{
Sun-Mi Jung ${ }^{1 *}$, Woon Kyu Lee ${ }^{2 *}$, \\ Jin-Oh Kwak', Sang Yong Jung ${ }^{1}$, \\ Jinyoung Park ${ }^{1}$, Wan-Young Kim ${ }^{3}$, \\ Jin $\mathrm{Kim}^{3}$ and Seok Ho Cha ${ }^{1,4}$ \\ ${ }^{1}$ Department of Pharmacology and Toxicology, \\ and Center for Advanced Medical Education by BK21 Project \\ Inha University \\ Incheon 400-103, Korea \\ ${ }^{2}$ Department of Laboratory Animal \\ Medical Research Center \\ College of Medicine, Yonsei University \\ Seoul 120-752, Korea \\ ${ }^{3}$ Department of Anatomy and \\ Cell Death Disease Research Center for MRC \\ College of Medicine, The Catholic University of Korea \\ Seoul 137-701, Korea \\ ${ }^{4}$ Corresponding author: Tel, 82-32-890-0957; \\ Fax, 82-32-890-0957; E-mail, shcha@inha.ac.kr \\ ${ }^{*}$ These authors contributed equally to this work.
}

Accepted 21 July 2006

Abbreviations: $\mathrm{AA}$, arcuate artery; $\mathrm{AV}$, arcuate vein; $\mathrm{EST}$, expressed sequence tag; IMCD, inner medullary collecting duct; OATLP, organic anion transporter like protein

\begin{abstract}
The organic anion transporters (OATs) are expressed in various tissues, primarily in the kidney and liver, but they are also expressed in the placenta, small intestine, and the choroid plexus, which are all epithelial tissues that transport xenobiotics. Six isoforms of OATs are currently known. Considering the variety of organic anionic compounds, other OATs isoforms can be assumed. In this connection, we have searched for a new isoform in the expressed sequence tag (EST) database. We found the new candidate clone AK052752 in the mouse kidney cDNA library and we named it mouse organic anion transporter like protein 1 (mOATLP1). The mOATLP1 cDNA consisted of 2221 base pairs that encoded a 552 amino acid residue protein with 12 putative transmembrane domains. The deduced amino acid sequence of mOATLP1 showed 37 to $63 \%$ identity to other members of the OAT family. According to
\end{abstract}

the tissue distribution based on Northern blot analysis, $2.7 \mathrm{~kb}$ and $2.9 \mathrm{~kb}$ mOATLP1 transcripts (approximate sizes) were observed in the kidney and liver. An $85-\mathrm{kDa}$ band (approximate) was detected using Western blot analysis of mouse kidney performed with a synthesized oligopeptide-induced mOATLP1 antibody. Immunohistochemical results showed mOATLP1 was stained in the blood vessels, glomeruli (the parietal epithelial cells and podocytes), distal convoluted tubules, connecting tubules, and inner medullary collecting tubules. mOATLP1 appears to be a novel candidate for an organic anion transporter isoform identified in the kidney.

Keywords: cloning, molecular; kidney; mouse; organic anion transporters

\section{Introduction}

The kidney and liver play a primary role in excretion of endogenous and exogenous compounds and their metabolites (Moller and Sheikh, 1982; Pritchard and Miller, 1993; Ullrich and Rumrich, 1993; Meier, 1995; Muller and Jansen, 1997). In addition to performing glomerular filtration, the kidney excretes charged compounds via the carrier-mediated organic anion and organic cation transport pathways in the renal proximal tubular cells (Sperber, 1959; Weiner and Mudge, 1964; Ullrich and Rumrich, 1988; Pritchard and Miller, 1991). In particular, the organic anion transport pathway is known to mediate the elimination of various organic anionic compounds.

Before the early 1990s, renal organic anion transport was thought to be carried out by a few carrier proteins with a wide substrate specificity. Various anionic substances are taken-up into the proximal tubular cells by the "classical PAH ( $p$-aminohippurate) transporter". Transepithelial transport of organic anions in proximal tubules is carried out by two distinct transporter: first, organic anions are transported from the blood by basolateral organic anion transporter(s), and subsequently effluxed into the tubular lumern by luminal transporter(s) (Marshall and Vicker, 1923). In 1999, the classical $\mathrm{PAH}$ transporter that is expressed in the basolateral membranes of proximal tubular cells was cloned from rat kidney. It was designated as rOAT1 (rat organic anion transporter 1) (Sekine et al., 1997). 
Several isoforms of OAT have been reported during this decade. Six isoforms and their orthologs have been identified and characterized (Sekine et al., 2000; Monte et al., 2004; Youngblood et al., 2004). These transporters are expressed mainly in the kidney and liver. Among these, hOAT4 is expressed in the placenta and mOAT6 is expressed in the olfactory mucosa. The substrate specificity of these transporters is multispecific, except for mOAT6. Considering the multispecificity of the substrates and the kinds of organic anion substances in the body, other OAT isoforms probably exist.

We used homology screening to search for new OAT isoforms, finding an EST clone. We identified the cDNA (named mOATLP1) by using the hybridization cloning method, and herein report on isolating a novel isoform of OAT that is expressed in the kidney.

\section{Materials and Methods}

\section{Materials \\ $\left[{ }^{32} \mathrm{P}\right] \mathrm{dCTP}$ was purchased from Amersham Pha- rmacia Biotech (Uppsala, Sweden). Taq DNA polymerase was obtained from Super-Bio Co., Ltd. (Suwon, Korea). TRI Reagent for RNA isolation was a product of Sigma-Aldrich (St. Louis, MO). PCR primers, dNTP mixture, and AMV reverse trans- criptase $\mathrm{XL}$ were purchased from TaKaRa Korea Biomedical Co. (Seoul, Korea). All other chemicals used in this study were of the highest purity available from commercial sources. \\ Reverse transcription-PCR and Isolation of mOATLP1}

The EST (expressed sequence tag) database was searched for "query hOAT4" resulting in identification of the EST clone AK052752. Primers, designed based on the nucleotide sequence, were forward primer, 5'-ATTCAAATTGGCAGCTTGGGGAGG-3' and reverse primer, 5'-ACAGTGTCTGTCCAACTCCTGAGG-3'. Using this set of primers, we performed RT-PCR on mouse kidney total RNA. The PCR protocol was $94^{\circ} \mathrm{C}$ for $10 \mathrm{~s}, 57^{\circ} \mathrm{C}$ for $30 \mathrm{~s}$, and $72^{\circ} \mathrm{C}$ for $30 \mathrm{~s}$ for 35 cycles (Kwak et al., 2005). The PCR product was subcloned into the TA cloning vector and the sequence was confirmed. The $\left[{ }^{32} \mathrm{P}\right]$ dCTP-labeled probe was synthesized from the PCR clone and used for screening of a mouse kidney cDNA library. A non-directional cDNA library was prepared from mouse kidney poly $(A)+$ RNA using the Superscript Choice system (Life Technologies), and the cDNAs were ligated into ZipLox EcoRI arms. Replicated filters of a phage library were hybridized overnight at $37^{\circ} \mathrm{C}$ in a hybridization solution $(50 \%$ formamide, $5 \times$ standard saline citrate (SSC), $3 \times$ Denhardt's solution, $0.2 \%$ SDS, $10 \%$ dextran sulfate, $0.2 \mathrm{mg} / \mathrm{ml}$ of denatured salmon sperm DNA, $2.5 \mathrm{mM}$ sodium pyrophosphate, $25 \mathrm{mM}$ MES, and $0.01 \%$ Antifoam B, pH 6.5), then washed at $37^{\circ} \mathrm{C}$ in $0.1 \times$ SSC and 0.1\% SDS (Kusuhara et al., 1999; Eun et al., 2001).

\section{Sequence determination}

Specially synthesized oligonucleotide primers were used for sequencing mOATLP1 cDNA by the dyetermination method using $\mathrm{ABI}$ Prism ${ }^{\mathrm{TM}} 3730$.

\section{Computational analysis}

Peptide sequences of the OAT family were obtained from GenBank (http://www.ncbi.nlm.nih.gov) and were aligned using CLUSTALW (http://helix.genes. nig.ac.jp/homology/top.html). Dendrograms were generated from the CLUSTALW output using TreeView (http://taxonomy.zology.gla.ac.uk). Topologies for mOATLP1 were predicted using TMpred (http:// www.ch.embnet.org/software/TMPRED_form.html). Other sequence analysis was performed using DNAsis (Hitachi, Japan).

\section{Northern blot analysis}

A commercially available hybridization blot containing poly $(A)^{+}$RNA from various mouse tissues (mouse 8-lane multiple tissue Northern (MTN) ${ }^{\mathrm{TM}}$ blot, CLONTECH) was used for Northern blot analysis of mOATLP1. We used full size mOATLP1 cDNA as a probe. The master blot filter was hybridized with the probe overnight at $42^{\circ} \mathrm{C}$ according to the manufacturer's instructions. The filter was washed in a high stringency condition $(0.1 \times$ SSC $(1 \times$ SSC $=$ $0.15 \mathrm{M} \mathrm{NaCl}$ and $0.015 \mathrm{M}$ sodium citrate) and $0.1 \%$ SDS at $\left.65^{\circ} \mathrm{C}\right)$.

\section{Western blotting and antibody specificity}

Western blot analysis was performed following the method of Jung et al. (2005), with slight modification. For preparation of a polyclonal antibody to mOATLP1, rabbits were immunized with the keyhole limpet hemocyanin-conjugated synthesized peptide CHDVGNDWKESRQAKEED corresponding to cysteine and the 17 amino acids near the $\mathrm{COOH}$ terminus of mOATLP1. The kidney was perfused with ice-cold phosphate buffered saline $(\mathrm{pH}$ 7.4) for removal of blood. Subsequently, the removed kidney was homogenized in 9 volumes of lysis buffer containing 2.1 M sucrose, $200 \mathrm{mM}$ HEPES ( $\mathrm{pH} 7.4), 1 \mathrm{mM}$ EDTA, and a protease inhibitor mixture (1 mM DTT, 
$1 \mathrm{mM}$ PMSF, $10 \mu \mathrm{g} / \mathrm{ml}$ of leupeptin, $10 \mu \mathrm{g} / \mathrm{ml}$ of trypsin inhibitor, and $2 \mu \mathrm{g} / \mathrm{ml}$ of aprotinin) in a Teflon/glass tissue homogenizer. After centrifugation at $500 \times g$ for $5 \mathrm{~min}$, the resulting supernatant was recentrifuged at $8,000 \times g$ for $10 \mathrm{~min}$. The supernatants were then centrifuged at $100,000 \times g$ for 1 $\mathrm{h}$, and the pellets containing crude membrane fractions were subjected to Western blotting (Cha et al., 2004). The protein concentration of the prepared sample was determined using a BCA protein assay kit (Pierce, Rockford, IL). An equal amount of protein were mixed with a 2 fold concentrated loading buffer (100 mM Tris HCl, pH 6.8, 2.5\% 2-mercaptoethanol, $10 \%$ glycerol, $4 \%$ SDS, $0.2 \%$ bromophenol and 200 $\mathrm{mM}$ DTT), heated for $10 \mathrm{~min}$ at $100^{\circ} \mathrm{C}$, and then subjected to electrophoresis on 9\% SDS-polyacrylamide gel. Separated protein was transferred onto a polyvinylidine fluoride (PVDF) membrane (Millipore, Bedford, MA) by electro-blotting, and non-specific binding sites were blocked by incubation with $5 \%$ non-fat dried milk in the TBST buffer $(10 \mathrm{mM}$ Tris $\mathrm{HCl}, \mathrm{pH} 7.4,100 \mathrm{mM} \mathrm{NaCl}$ and $0.1 \%(\mathrm{v} / \mathrm{v})$ Tween

A

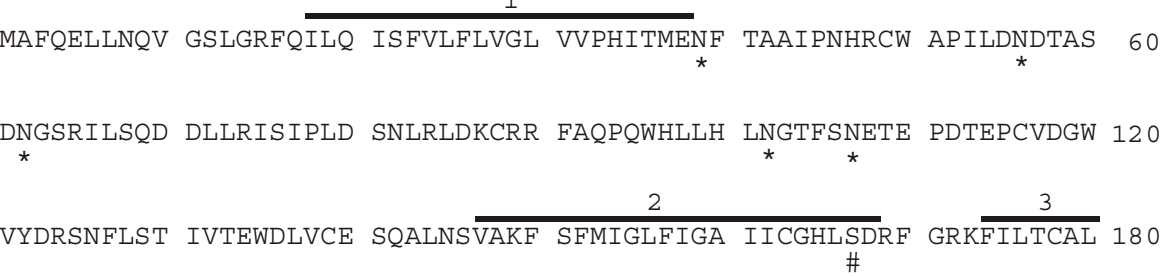

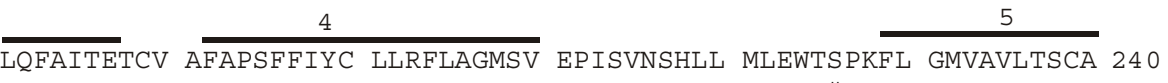
\#

\section{6}

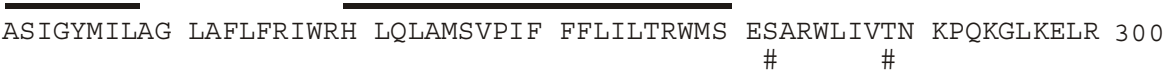
KVAHMNGMKN SGNTLTMEVV $\underset{\#}{\text { EASMKNELEA AKRKSSPRDL FHTPILRKRI CVLSFMRYLF } 360}$

$\frac{8}{\text { TISIFGLSLH LQHLSTNIIL LQFLSSALGI LISVIGHFVL NHMGRRITQL VLMSLRGIFM }} 420$

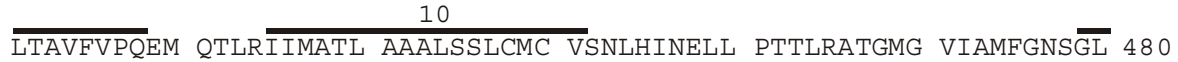

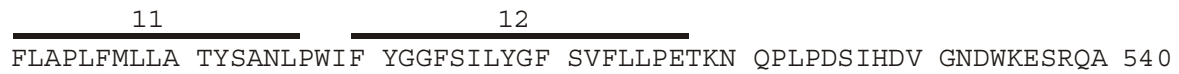

KEEDSIIKVT RF

B

$2 \begin{array}{lllll}2 & 3 & 4 & 5 & 6\end{array}$

$\begin{array}{llllll}7 & 8 & 9 & 10 & 11 & 12\end{array}$

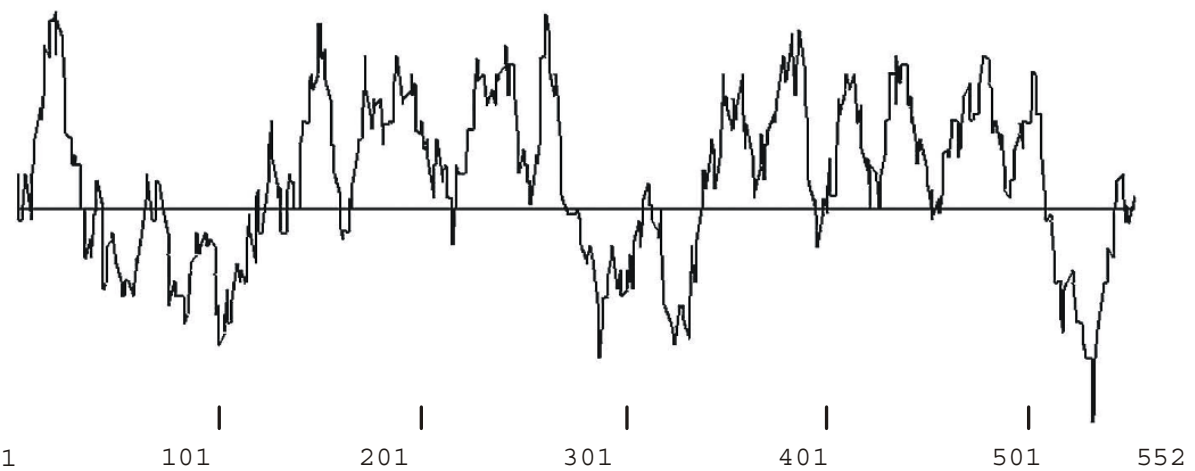

Figure 1. Amino acid sequence of mOATLP1 and hydropathy analysis. A. Amino acid sequence of mOATLP1. Potential N-glycosylation sites are indicated by asterisks and protein kinase $\mathrm{C}$ phosphorylation sites by sharps. B. KyteDoolittle hydropathy analysis of mOATLP1 (window of 11). Predicted membrane-spanning regions of

1

101

201

301

401

501 mOATLP1 are numbered 1-12. 
20) for $1 \mathrm{~h}$ with agitation. The PVDF membrane was then incubated for $1 \mathrm{~h}$ at room temperature with the antibody raised against mOATLP1 (1,000:1). For absorption analysis, preincubated mOATLP1 antibody with synthesized oligopeptide antigen (200 $\mu \mathrm{g} / \mathrm{ml}$ ) for $1 \mathrm{~h}$ at $37^{\circ} \mathrm{C}$ was applied. Afterwards, the membrane was incubated further for $1 \mathrm{~h}$ at room temperature with horseradish peroxidase conjugated secondary antibody (1:3,800 dilution). After washing the membrane with TBST buffer, protein bands on X-ray film were visualized by using an ECL detection kit following the manufacturer's instructions (Amersham Pharmacia Biotech, Buckinghamshire, UK).

\section{Immunohistochemical analysis}

The 1- $\mu \mathrm{m}$-thick vibratome sections were processed for immunohistochemistry using an indirect preembedding immunoperoxidase method. The sections were washed three times for 15 min each in PBS containing $50 \mathrm{mM} \mathrm{NH}_{4} \mathrm{Cl}$, then incubated for 4

A

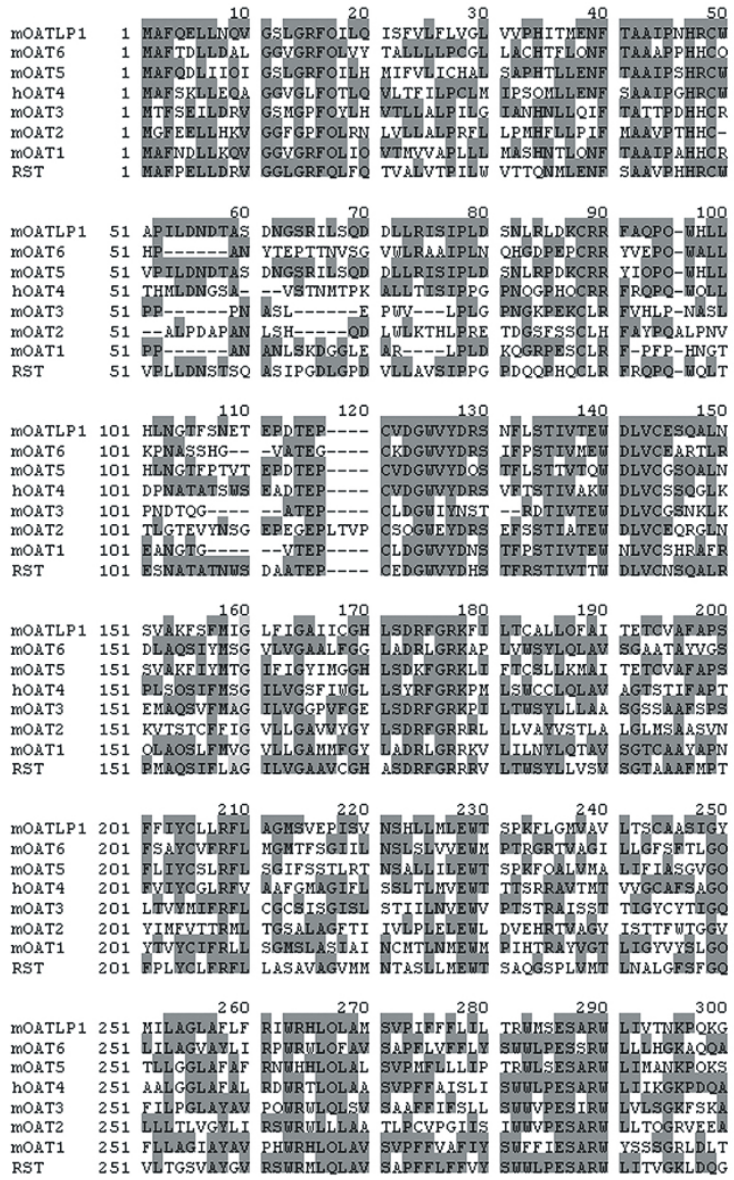

$\mathrm{h}$ in PBS containing $1 \% \mathrm{BSA}, 0.05 \%$ saponin, and $0.2 \%$ gelatin (solution $A$ ). The tissue sections were incubated overnight at $4{ }^{\circ} \mathrm{C}$ with mOATLP1 antibody diluted $1: 400$ in 1\% BSA in PBS (solution B). After several washes with PBS containing $0.1 \%$ BSA, $0.05 \%$ saponin, and $0.2 \%$ gelatin (solution $C$ ), the tissue sections were incubated for $2 \mathrm{~h}$ in a 1:100 dilution of a peroxidase-conjugated goat anti-rabbit IgG Fab fragment (Jackson ImmunoResearch Laboratories) in solution $\mathrm{B}$. The tissues were then rinsed, first in solution $C$ and subsequently in $50 \mathrm{mM}$ Tris- $\mathrm{HCl}(\mathrm{pH} 7.6)$. For the detection of horseradish peroxidase, the sections were incubated in $0.1 \%$ 3,3'-diaminobenzidine in Tris buffer for $5 \mathrm{~min}$, then colorization of reaction was performed with $0.01 \%$ $\mathrm{H}_{2} \mathrm{O}_{2}$ for incubation of approximately $10 \mathrm{~min}$. After washing in the Tris buffer, the sections were dehydrated in a graded series of ethanol and embedded in Epon 812 (Polysciences, Warrington, CA).

B

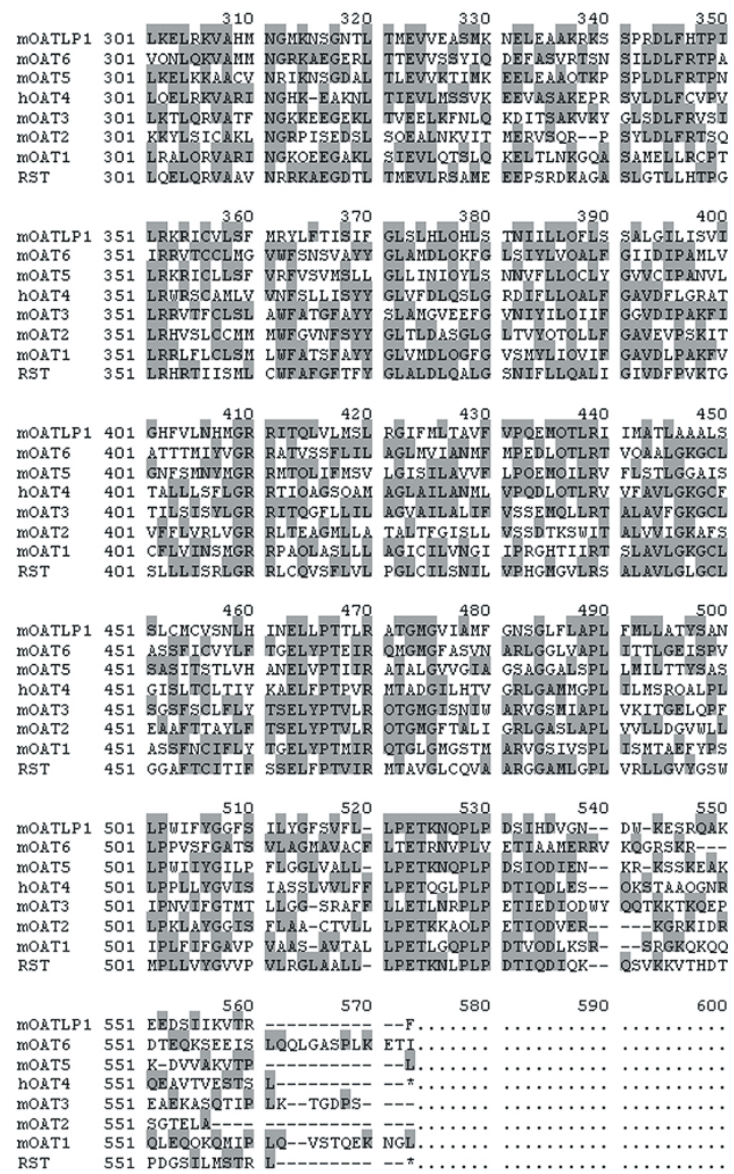

Figure 2. The amino acid sequence of mOATLP1 aligned with the sequences of mOAT1, mOAT2, mOAT3, hOAT4, mOAT5, mOAT6, and RST. Boxed residues indicate conserved residues in at least two transporters. AK052752 was used as a probe for screening mOATLP1. 
Table 1. Percent amino acid identity between fully sequenced organic anion transporters.

\begin{tabular}{|c|c|c|c|c|c|c|c|}
\hline & mOAT2 & mOAT3 & hOAT4 & mOAT5 & mOAT6 & mOATLP1 & RST \\
\hline mOAT1 & 40 & 50 & 42 & 40 & 48 & 40 & 46 \\
\hline mOAT2 & & 40 & 38 & 36 & 40 & 37 & 40 \\
\hline mOAT3 & & & 43 & 39 & 48 & 41 & 45 \\
\hline hOAT4 & & & & 45 & 45 & 46 & 51 \\
\hline mOAT5 & & & & & 40 & 63 & 45 \\
\hline mOAT6 & & & & & & 41 & 45 \\
\hline mOATLP1 & & & & & & & 45 \\
\hline
\end{tabular}

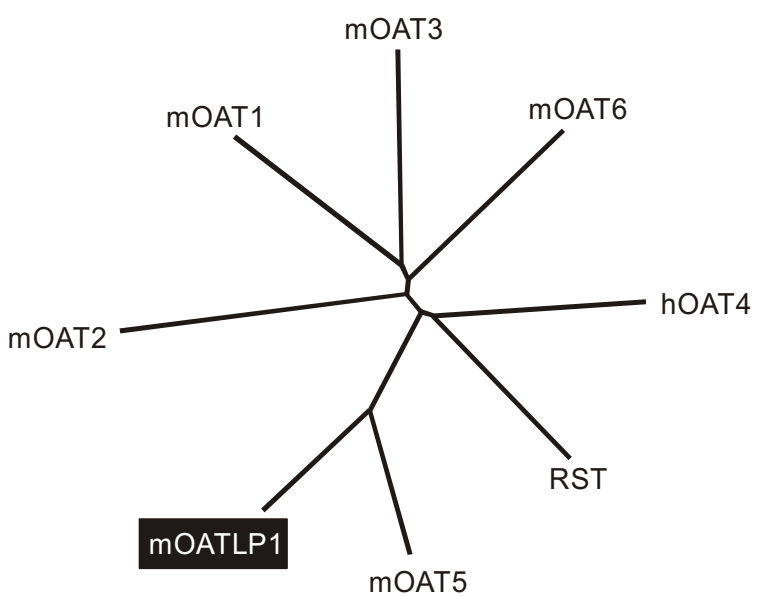

0.1

Figure 3. Dendrogram of the OAT family. Sequences of the indicated OAT family members were aligned using CLUSTALW and the alignment output was used to generate a dendrogram.

\section{Results}

\section{Structural features of novel mOATLP1}

The EST database search identified the EST clone AK052752 with significant identity to the OAT family. Using AK052752 as a probe, two positive clones were isolated by screening 320,000 plaques from the mouse kidney cDNA library. One clone was identified as mOAT5 and the other clone was identified as a novel membrane protein (mOATLP1) consisting of 2221 base pairs encoding a 552 amino acid residue protein. The membrane topology of mOATLP1 was analyzed using TMpred software and a Kyte \& Doolittle hydrophobicity analysis was performed resulting in identification of 12 putative transmembrane domains (Figure $1 \mathrm{~A}$ and $1 \mathrm{~B}$ ). Both the $\mathrm{N}$-terminus and $\mathrm{C}$-terminus were located in the intracellular space. As shown in Figure 1A, mOATLP1 contained five $\mathrm{N}$-glycosylation sites on the extracelluar surface between the first and second mem-

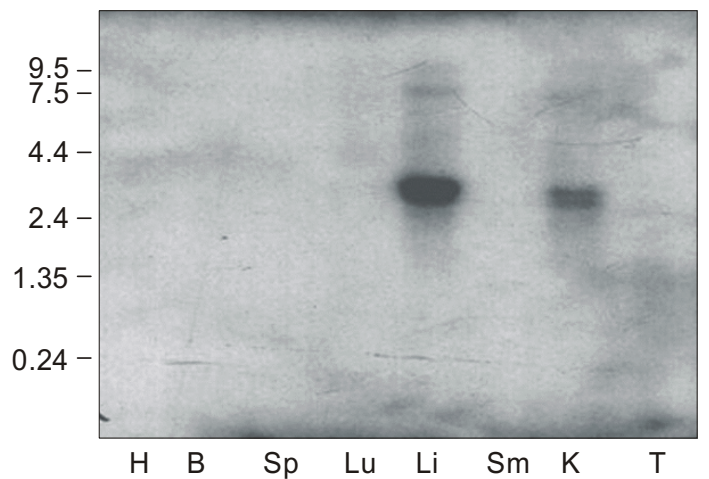

Figure 4. Northern blot analysis of mOATLP1. A mouse multiple tissue blot (CLONTECH, \#7762-1) containing $2 \mu \mathrm{g}$ of poly $(A)^{+}$RNA from 8 mouse tissues in each of the lanes was probed with a ${ }^{32} \mathrm{P}$-labeled mOATLP1 cDNA fragment and was washed under highly stringent conditions. H, heart; B, brain; Sp, spleen; Lu, lung; Li, liver; Sm, skeletal muscle; $\mathrm{K}$, kidney; $\mathrm{T}$, testis.

brane spanning domains. mOATLP1 also contained six protein kinase $C$ (PKC) phosphorylation sites on the intracellular surface. Among these PKC sites, four PKC phosphorylation sites were located between the sixth and seventh membrane spanning domains, similar to other known OATs.

\section{Relationship of mOATLP1 to the other OAT family members}

We compared the mOATLP1 sequence to other members of the OAT family (Figure 2). The amino acid homologies of OATs were in the range of $37 \%$ to $63 \%$. Among the OATs, mOATLP1 showed $63 \%$ amino acid homology to mOAT5 and high homologies to hOAT4 and RST $(46 \%$ and $45 \%$, respectively) (Table 1). We aligned the peptide sequences of the known OATs and mOATLP1 to generate a dendrogram delineating their phylogeny (Figure 3). The phylogenetic tree showed that mOATLP1 was located nearest to mOAT5. 


\section{Tissue distribution of mOATLP1}

In order to demonstrate the tissue distribution of mOATLP1 mRNA, Northern blot analysis was performed for tissues of various mouse organs (heart, brain, spleen, lung, liver, skeletal muscle, kidney, and testis). When the hybridization was performed with full length mOATLP1, $2.7 \mathrm{~kb}$ and a $2.9 \mathrm{~kb}$ mOATLP1 transcripts (approximate sizes) were identified in kidney and liver tissues at $12 \mathrm{~h}$ of exposure (Figure 4). Expression of mOATLP1 transcripts was not detected in other tissues after a long exposure (more than three days).

\section{Western blot analysis of mOATLP1 in the kidney by using the synthesized $\mathrm{C}$-terminus oligopeptide that originated from rabbit anti-serum}

Western blot analysis was performed on the membrane fraction prepared from mouse kidney. Bands of approximately $85-\mathrm{kDa}$ were detected for mOATP1. As shown in Figure 5, these immunoreactive bands

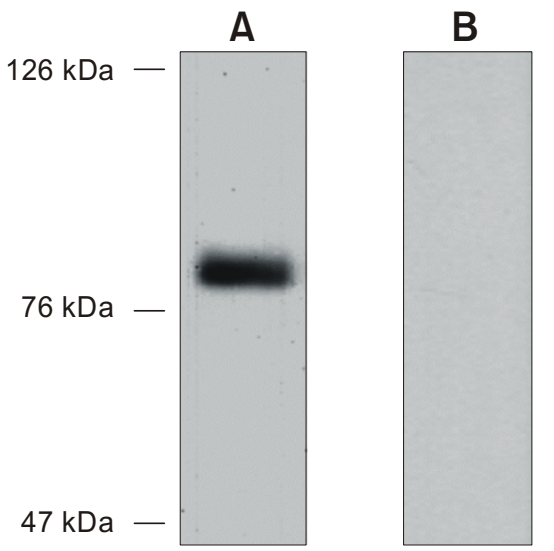

Figure 5. Western blot analysis of mOATLP1. The membrane fraction $(20 \mu \mathrm{g} /$ lane) was boiled with the same volume of $2 \times$ loading buffer for $10 \mathrm{~min}$ and separated by electrophoresis on 9\% SDS/PAGE gel. Protein transferred membrane was treated with the first antibody $(A)$ or the preabsorbed first antibody (B). Afterwards, the membrane was incubated for $1 \mathrm{~h}$ at room temperature with horseradish peroxidase conjugated secondary antibody (1:3800 dilution). After washing the membranes in TBST buffer, protein bands on X-ray film were visualized using an ECL detection kit following the manufacturer's instructions.
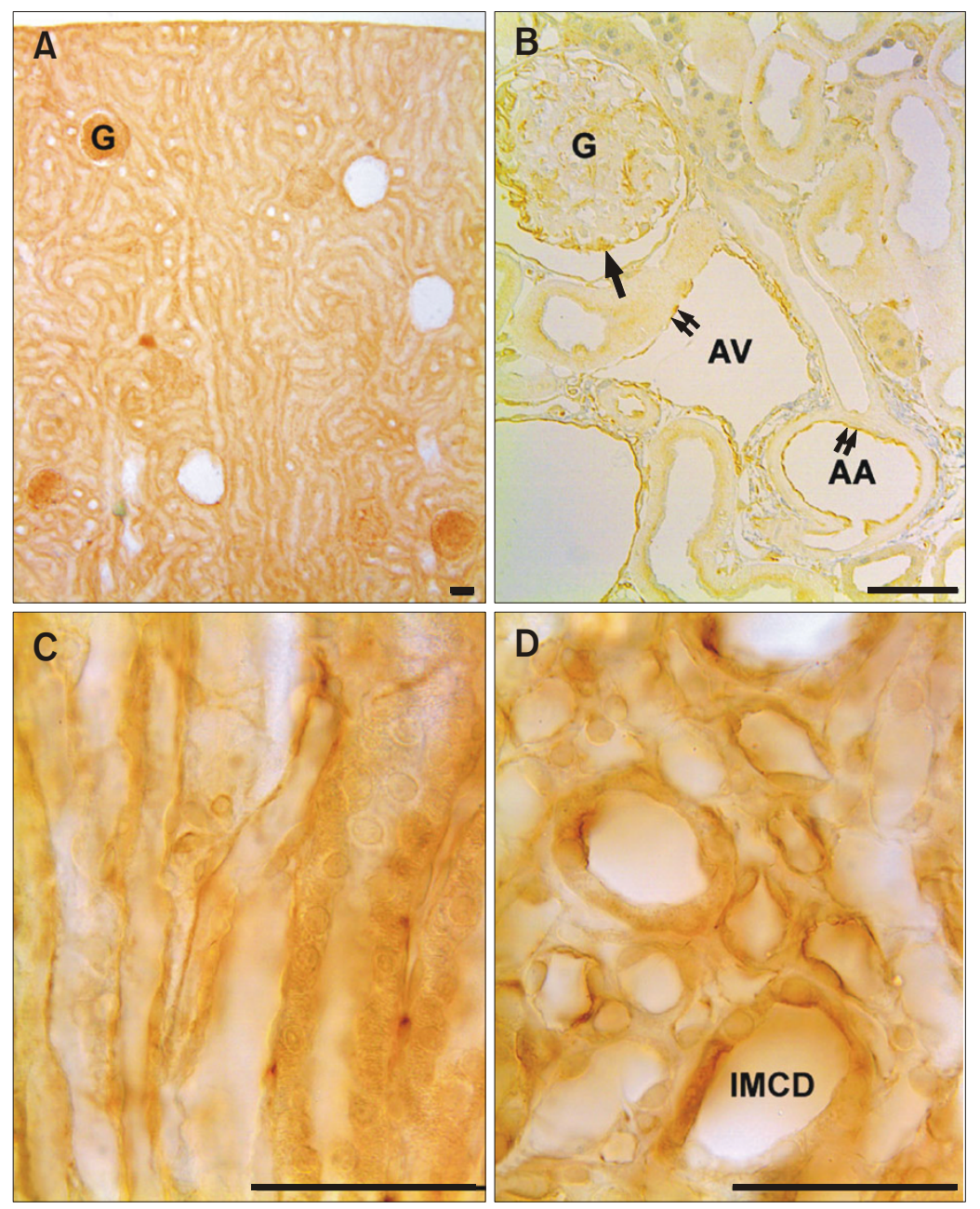

Figure 6. Immunohistochemical analysis of mOATLP1 in mouse kidney. One-micrometer sections were incubated with polyclonal antibody against mOATLP1. Parietal epithelial cells and podocytes in the glomerulus and the apical membrane of distal convoluted and collecting tubules were stained. No staining was observed in the proximal and thick ascending limbs (bars indicate $10 \mu \mathrm{m}$ ). G, glomerulus; $A A$, arcuate artery; $A V$, arcuate vein. 
disappeared using the preabsorbed antibody with an oligepeptide antigen solution $(200 \mu \mathrm{g} / \mathrm{ml})$. Antibody specificity was confirmed by these results.

\section{Immunohistochemistry of mOATLP1 in mouse kidney}

Light microscopic analysis of $1-\mu \mathrm{m}$ thick vibratome sections demonstrated that there was specific immunostaining of mOATLP1 in the blood vessels, glomerulus (the parietal epithelial cells and the podocytes), distal convoluted tubules, connecting tubules, and inner medullary collecting tubules (Figure 6). There was no staining of mOATLP1 in the proximal tubule and thick ascending limbs. Under high magnification, mOATLP1 was observed in the apical membranes of the immuno-positive tubules (Figure $6 \mathrm{C}$ and D).

\section{Discussion}

We report on isolation of a novel mouse organic anion transporter like protein 1 (mOATLP1) that encodes a 552 amino acid residue protein showing 37 to $63 \%$ identity to other OATs and RST. We conducted this study to search the expressed sequence tag database using the hOAT4 amino acid sequence because there has been no report regarding isolation and characterization of rat or mouse orthologs. We found one EST clone (AK052752) and we screened the mouse kidney cDNA library using low stringent hybridization. We cloned two positive sequences from 320,000 plaques. One sequence was identified as the previously reported mOAT5 clone (Youngblood et al., 2004). The other sequence was identified as a novel clone (mOATLP1). These clones exhibited 63\% identity in their amino acid sequences. mOATLP1 exhibited amino acid homology from $37 \%$ to $63 \%$ (Lopez-Nieto et al., 1997; Brady et al., 1999; Cha et al., 2000; Kobayashi et al., 2002; Monte et al., 2004; Youngblood et al., 2004). Human OAT4 also exhibited high homology to mOATLP1 (51\%). Phylogenic analysis of the reported murine OAT and human OAT4 showed that OTA7 formed a cluster with hOAT4 and mOAT5. As shown Figure 1, mOATLP1 has 12 putative membrane spanning domains, one extracellular long loop between the first and second transmembrane domains, and one intracellular long loop between the sixth and seventh transmembrane domains, all similar to the other known OAT isoforms. In addition, multiple protein kinase $C$ phosphorylation sites were also conserved in the intracellular loop, and $\mathrm{N}$-glycosylation sites were also conserved in the extracellular long loop. Alignment of the OAT amino acid sequences revealed that the signature sequence motifs of OATs
(STIVTEWD and ELYPT) are conserved throughout the slc22 family, including mOATLP1 with some minor variations (Schomig et al., 1998). Phylogenetic analysis revealed that mOATLP1 is located at a position nearest to mOAT5, probably related to similar substrate selectivity. Youngblood and Sweet (2004) reported that the typical substrate of mOAT5 is ochratoxin A. Our results showed that mOAT5 transports ochratoxin A, estrone sulfate, and dehydroepiandrosterone sulfate with a high affinity. However, we could not determine the typical substrate of mOATLP1 using at least 12 isotope labeled compounds and the Xenopus laevis oocyte expression system ( $\left[{ }^{14} \mathrm{C}\right]$ para-aminohippurate, $\left[{ }^{3} \mathrm{H}\right]$ dehydroepiandrosterone sulfate, $\left[{ }^{3} \mathrm{H}\right]$ estrone sulfate, $\left[{ }^{14} \mathrm{C}\right]$ carnitine, $\left[{ }^{14} \mathrm{C}\right]$ salicylate, $\left[{ }^{3} \mathrm{H}\right]$ prostaglandin $\mathrm{E} 2,\left[{ }^{3} \mathrm{H}\right]$ cycloadenosine monophosphate, $\left[{ }^{3} \mathrm{H}\right]$ estradiol $17 \beta$-D-glucuronide, $\left[{ }^{14} \mathrm{C}\right]$ tetraethyl ammonium bromide, $\left[{ }^{74} \mathrm{C}\right]$ uric acid, $\left[{ }^{3} \mathrm{H}\right]$ methotrexate and $\left[{ }^{3} \mathrm{H}\right]$ ochratoxin $\left.\mathrm{A}\right)$. The substrate specificity of the recently identified olfactory mucosa mOAT6 was not determined. It is important to determine the typical substrates of the transporters in order to gain a better understanding of the role of each organic transporter in the body. Therefore, extensive study will be necessary to determine the substrate of each transporter.

The mRNA expression of mOATLP1 in tissues was observed in both the kidney and liver. Almost all of the OAT isofoms are expressed in the kidney, except for mOAT6, which is predominantly expressed in olfactory mucosa and it is slightly expressed in the testis. However, some degree of tissue specificity does exist (mOAT5 is only expressed in the kidney). The tissue distribution of mOATLP1 is similar to the distribution of mOAT2 (both are expressed in the kidney and liver). This mRNA expression was not detected in other tissues with increased exposure time using polymerase chain reaction with a specific primer (up to $45 \mathrm{PCR}$ cycles). Considering the homologies, the tissue distributions, and the substrate specificities of OAT2 and OAT5, there is a need to perform mOATLP1mediated uptake analyses with other steroid conjugates (sulfate or glucuronide).

Western blot analysis of mOATLP1 detected a corresponding band (approx. $85 \mathrm{kDa}$ ). This band disappeared via absorption with the synthesized oligopeptide antigen. The molecular weight that was calculated from the amino acid was 60736.8 Da, showing that mOATLP1 may be glycosylated.

The localization of OATs in the intranephron is important for understanding the direction of movement of the organic anionic substance. The OAT1 and OAT3 proteins are known to be localized to the basolateral membrane, and OAT2 and OAT4 are known to be localized in the apical membrane of 
nephrons (Hosoyamada et al., 1999; Cha et al., 2001; Babu et al., 2002; Kojima et al., 2002). Our results showed that the mOAT5 protein was localized in the apical membrane of the late proximal tubule. Immunohistochemical results showed that mOATLP1 proteins were localized at the apical membrane of nephrons. mOATLP1 was identified on the podocytes and parietal epithelial cells in the glomerulus. In addition, mOATLP1 was detected in the distal convoluted and inner medullary collecting tubules. We speculate that this protein contributes to the transepithelial movement of drugs/chemicals that act in the glomerulus, distal tubules, or collecting tubules.

In conclusion, we report here on the identification of mOATLP1 that is predominantly expressed in the kidney and it is moderately expressed in the liver. Amino acid homology and phylogenetic analyses showed that this protein probably belongs to the organic anion transporter family. Additional studies regarding the transport properties of mOATLP1 are indicated.

\section{Acknowledgement}

This work was supported by Korea Research Foundation Grants (KRF-2004-202-C00373 and KRF-2005-003-E00042) and a Korea Health 21 R\&D Project, Ministry of Health \& Welfare, R.O.K grant (03-PJ10-PG13-GD01-0002).

\section{References}

Babu E, Takeda M, Narikawa S, Kobayashi Y, Enomoto A, Tojo A, Cha SH, Sekine T, Sakthisekaran D, Endou H. Role of human organic anion transporter 4 in the transport of ochratoxin A. Biochim Biophys Acta 2002;1590:64-75

Brady KP, Dushkin H, Fornzler D, Koike T, Magner F, Her H, Gullans S, Segre GV, Green RM, Beier DR. A novel putative transporter maps to the osteosclerosis (oc) mutation and is not expressed in the oc mutant mouse. Genomics 1999;56: 254-61

Cha SH, Sekine T, Kusuhara H, Yu E, Kim JY, Kim DK, Sugiyama $\mathrm{Y}$, Kanai $\mathrm{Y}$, Endou $\mathrm{H}$. Molecular cloning and characterization of multispecific organic anion transporter 4 expressed in the placenta. J Biol Chem 2000;275:4507-12

Cha SH, Sekine T, Fukushima JI, Kanai Y, Kobayashi Y, Goya $\mathrm{T}$, Endou $\mathrm{H}$. Identification and characterization of human organic anion transporter 3 expressing predominantly in the kidney. Mol Pharmacol 2001;59:1277-86

Eun BK, Lee B, Kang HM. Cloning and expression of cryptochrome2 cDNA in the rat. Mol Cells 2001;12:286-91

Hosoyamada M, Sekine T, Kanai Y, Endou H. Molecular cloning and functional expression of a multispecific organic anion transporter from human kidney. Am J Physiol 1999;276: F122-F8
Jung SY, Kwak JO, Kim HW, Kim DS, Ryu SD, Ko CB, Cha SH. Calcium sensing receptor forms complex with and is up-regulated by caveolin-1 in cultured human osteosarcoma (Saos-2) cells. Exp Mol Med 2005;37:91-100

KobayashiY, Ohshiro N, Shibusawa A, Sasaki T, Tokuyama $\mathrm{S}$, Sekine $\mathrm{T}$, Endou H, Yamamoto T. Isolation, characterization and differential gene expression of multispecific organic anion transporter 2 in mice. Mol Pharmacol 2002;62:7-14

Kojima R, Sekine T, Kawachi M, Cha SH, Suzuki Y, Endou H. Immunolocalization of multispecific organic anion transporters, OAT1, OAT2, and OAT3, in rat kidney. J Am Soc Nephrol 2002;13:848-57

Kusuhara H, Sekine T, Utsunomiya-Tate N, Tsuda M, Kojima $\mathrm{R}$, Cha SH, Sugiyama Y, Kanai Y, Endou H. Molecular cloning and characterization of a new multispecific organic anion transporter from rat brain. J Biol Chem 1999;274:13675-80

Kwak JO, Kim HW, Oh KW, Kim DS, Han KO, Cha SH. Co-localization and interaction of organic anion transporter 1 with caveolin-2 in rat kidney. Exp Mol Med 2005;37:204-12

Lopez-Nieto CE, You G, Bush KT, Barros EJ, Beier DR, Nigam SK. Molecular cloning and characterization of NKT, a gene product related to the organic cation transporter family that is almost exclusively expressed in the kidney. J Biol Chem 1997;272:6471-8

Marshall EKJ, Vicker JL. The mechanisms of the elimination of phenolsulphonphthalein by the kidney - a proof of secretion by the convoluted tubules. Bull Johns Hopkins Hosp 1923;34:1-7

Meier PJ. Molecular mechanisms of hepatic bile salt transport from sinusoidal blood into bile. Am J Physiol 1995;269: G801-G12

Moller JV, Sheikh MI. Renal organic anion transport system: pharmacological, physiological, and biochemical aspects. Pharmacol Rev 1982;34:315-58

Monte JC, Nagle MA, Eraly SA, Nigam SK. Identification of a novel murine organic anion transporter family member, OAT6, expressed in olfactory mucosa. Biochem Biophys Res Commun 2004;323:429-36

Muller M, Jansen PL. Molecular aspects of hepatobiliary transport. Am J Physiol 1997;272:G1285-G303

Pritchard JB, Miller DS. Comparative insights into the mechanisms of renal organic anion and cation secretion. Am J Physiol 1991;261:R1329-R40

Pritchard JB, Miller DS. Mechanisms mediating renal secretion of organic anions and cations. Physiol Rev 1993; 73:765-96

Schomig E, Spitzenberger F, Engelhardt M, Martel F, Ording $\mathrm{N}$, Grundemann D. Molecular cloning and characterization of two novel transport proteins from rat kidney. FEBS Lett 1998;425:79-86

Sekine T, Watanabe N, Hosoyamada M, Kanai Y, Endou H. Expression cloning and characterization of a novel multispecific organic anion transporter. J Biol Chem 1997;272: 18526-9 
Sekine T, Cha SH, Endou $\mathrm{H}$. The multispecific organic anion transporter (OAT) family. Eur J Physiol 2000;440:337-50 Sperber I. Secretion of organic anions in the formation of urine and bile. Pharmacol Rev 1959;11:109-34

Ullrich KJ, Rumrich G. Contraluminal transport systems in the proximal renal tubule involved in secretion of organic anions. Am J Physiol 1988;254:F453-F62

Ullrich KJ, Rumrich G. Renal transport mechanisms for xenobiotics: chemicals and drugs. Clin Investig 1993;71:
843-8

Weiner I, Mudge GH. Renal tubular mechanisms for excretion of organic acids and bases. Am J Med 1964;36:743-62

Youngblood GL, Sweet DH. Identification and functional assessment of the novel murine organic anion transporter Oat5 (Slc22a19) expressed in kidney. Am J Physiol 2004;287: F236-F44 